\title{
TRADISI BURU BABI MASYARAKAT MINANGKABAU: PROSES, MAKNA, DAN DRAMA SOSIAL
}

\author{
(Pig Hunting Tradition in Minangkabau: Its Process, Meaning, and Social Drama)
}

\author{
Eva Yenita Syam \\ Badan Pengembangan dan Pembinaan Bahasa \\ Jalan Daksinapati Barat IV, Rawamangun, Jakarta Timur 13220 \\ Pos-el: perempuanlaut@gmail.com
}

(Naskah Diterima 4 November 2021-Direvisi 17 November 2021-Disetujui 19 November 2021)

\begin{abstract}
Pig hunting in Minangkabau is a rite of passage which is carried out in a gradual ritual process. The rite of pig hunting is a sign that involves various social aspects of the community, including economy, religion and culture. There are two questions to be answered in this research. Firstly, what is the meaning of the rite in the society, and secondly, how does the community's traditional pig hunting construct a social drama. To answer those questions, the author uses Victor Turner's ritual theory and Max Weber's theory of social drama. The results of this study indicate two main things. First, the pig hunting, which was originally an attempt to eliminate pests, later developed into a social drama. The rite of hunting as a social drama has four functions, namely (1) eliminating conflict; (2) limiting divisions and building community solidarity; (3) unites two opposing principles; and (4) provides new strength and motivation to live in everyday society. Second, as a social drama, the tradition forms a social construction. In this social process, there are four phases of social drama, (1) violation of social norms which invites the community to unite in eradicating pests; (2) wild pests pose a real threat, which can make the life of the farming community miserable (crisis) so that the community unites and holds various ceremonies to prepare for the implementation of hunting; (3) crisis recovery measures by carrying out a pig hunting ceremony; and (4) returns society with its entire social order to a normal situation.
\end{abstract}

Keywords: crisis, norms, oral tradition, social construction, social drama

\begin{abstract}
Abstrak
Buru babi dalam masyarakat Minangkabau merupakan sebuah ritus yang dilaksanakan dalam sebuah proses ritual yang bertahap. Ritus buru babi menjadi sebuah penanda yang melibatkan berbagai aspek sosial masyarakat Minangkabau, termasuk ekonomi, religi, dan budaya. Ada dua hal yang hendak dijawab di dalam penelitian ini, yaitu makna ritus buru babi dalam masyarakat Minangkabau dan bagaimana konstruksi sosial dari proses ritual tradisi buru babi sebagai sebuah drama sosial. Untuk menjawab kedua pertanyaan tersebut, penulis menggunakan teori ritual Victor Turner dan teori drama sosial Max Weber. Hasil penelitian ini menunjukkan dua hal pokok. Pertama, peristiwa buru babi yang awalnya hanya merupakan upaya para petani menghilangkan hama tanaman berkembang menjadi sebuah drama sosial. Ritus buru babi sebagai drama sosial ternyata memiliki empat fungsi, yaitu (1) menghilangkan konflik; (2) membatasi perpecahan dan membangun solidaritas masyarakat; (3) mempersatukan dua prinsip yang bertentangan; dan (4) memberikan kekuatan dan motivasi baru untuk hidup dalam masyarakat sehari-hari. Kedua, sebagai drama sosial, tradisi buru babi membentuk sebuah konstruksi sosial. Di dalam proses sosial itu terdapat empat fase drama
\end{abstract}


sosial yang terdiri atas (1) pelanggaran norma sosial oleh hama yang mengundang masyarakat untuk bersatu melakukan pembasmian; (2) hama babi mendatangkan ancaman yang nyata yang dapat menyengsarakan kehidupan masyarakat petani (krisis) sehingga masyarakat bersatu dan mengadakan berbagai upacara persiapan pelaksanaan berburu; (3) tindakan pemulihan krisis dengan melaksanakan upacara berburu babi; dan (4) mengembalikan masyarakat dengan seluruh tatanan sosialnya ke dalam situasi normal.

Kata kunci: krisis, norma, tradisi lisan, konstruksi sosial, drama sosial

\section{PENDAHULUAN}

Ritual merupakan rekaman drama sosial yang mencerminkan memori kolektif sebuah komunitas, termasuk di dalamnya catatan mengenai aksi penandaan wilayah atau teritori (Turner, 1969). Pola pergerakan dalam ritual membentuk tatanan spasial dari komunitas pemangku adatnya. Teritori adalah ruang yang diberi batas atau cagar yang melibatkan identifikasi psikologis terhadap tempat, seperti tindakan pengaturan dan sikap memiliki pada benda-benda yang berada di dalamnya. Batas dari sebuah teritori bisa dikenali lewat terjadinya perubahan perilaku dan sifat privasi ketika teritori tersebut ditembus. Berkaitan dengan status peralihan ini, ruang liminal adalah ruang ambang atau peralihan dari suatu kondisi ke kondisi lainnya yang di dalamnya terjadi perubahan, ketidakpastian, atau terbaliknya hierarki sosial yang menunjukkan sifat kegiatannya yang turun-temurun dilakukan oleh sebuah komunitas (Adisaputri \& Widiastuti, 2014).

Masyarakat Minangkabau mempunyai banyak tradisi unik yang menarik perhatian publik. Salah satunya adalah aktivitas berburu babi. Berburu babi merupakan salah satu tradisi yang dilestarikan secara turun-temurun oleh nenek moyang masyarakat Minangkabau. Berburu babi yang dilakukan masyarakat Minangkabau di Provinsi Sumatera Barat merupakan salah satu bentuk permainan rakyat yang telah mentradisi. Dengan bantuan hewan (anjing), masyarakat (laki-laki) memburu babi yang merusak lahan pertanian mereka. Ritus berburu babi itu merupakan sebuah drama sosial masyarakat Minangkabau untuk mempertahankan teritori mereka dari gangguan babi hutan.

Menurut Abdulah (Abdullah, 1966), berburu babi hutan diperkirakan dilakukan jauh sebelum lslam masuk dan berkembang di Minangkabau (praPadri). Aktivitas itu sebenarnya sudah lama dipraktikkan secara turun-temurun hingga generasi sekarang. Menariknya, kegiatan masyarakat ini tidak hanya dilakukan oleh masyarakat perdesaan, tetapi juga perkotaan yang suntuk dengan kegiatan sehari-hari. Perburuan terhadap hama babi hutan harus dilakukan di daerah-daerah perdesaan yang berbasis pertanian dan berbatasan langsung dengan hutan yang menjadi habitat berkembangnya babi secara alamiah.

Masyarakat Minangkabau mewarisi tradisi matrilineal. Namun, dalam tradisi buru babi, perempuan tidak dilibatkan. Mereka hanya sebatas menyediakan menu makanan (Arifin, 2012). Perempuan Minangkabau memiliki peranan yang cukup besar jika dibandingkan dengan laki-laki. Dalam urusan pembagian harta warisan, lakilaki tidak mendapatkan apa-apa karena harta, seperti tanah dan rumah, diwariskan kepada perempuan. Laki-laki dalam adat Minangkabau disebut sebagai urang asiang (orang luar). 
Arifin menambahkan bahwa menurut adat, seorang sumando adalah orang asing (orang luar) dalam kelompok istrinya yang ditunjukkan dalam pepatah bak abu di ateh tunggua (seperti abu di atas tunggul). Pepatah itu mengisyaratkan bahwa posisi seorang suami (sumando) sangat bergantung pada sejauh mana kebaikan hati keluarga istri, ibarat abu yang siap diterbangkan apabila angin kencang datang (Arifin, 2012).

Buru babi juga merupakan kompetisi di antara mereka yang berpartisipasi. Mereka saling membanggakan keterampilan diri dan anjingnya sehingga nilai jual anjingnya meningkat. Graves (Graves \& Novi Andri dkk., 2007) menjelaskan bahwa faktor utama yang menentukan dalam dinamika masyarakat Minangkabau tradisional adalah terdapatnya kompetisi yang konstan di antara individu dan keluarga-keluarga untuk mendapatkan penghargaan dan status, seperti posisiposisi yang dicapai secara mandiri atau posisi yang diperoleh dari kekuasaan dan prestise keturunan menurut adat.

Masyarakat Minang memandang bahwa buru babi merupakan ajang rasa dan periksa (raso jo pareso). Raso jo pareso tentang alam yang dijadikan guru dan unsur-unsurnya saling berbeda peranan dan sifatnya, tetapi berbaur dalam kedudukan yang sama pentingnya dalam kesemestaan. Demikian juga susunan masyarakat Minangkabau, suatu kumpulan yang utuh dengan beragam sifat manusia yang dapat menimbulkan berbagai kemungkinan, tetapi tidak saling mencelakai antarsesamanya.

Orang Minangkabau yang menjadikan raso jo pareso sebagai alat mempertimbangkan segala sesuatu mempunyai satu motivasi yang kuat untuk hidup dinamis, yakni memelihara harga diri yang tidak terkalahkan atau tidak terendahkan sehingga tidak memalukan. Untuk itu, mereka berlomba dan bersaing dalam lingkungan harmoni alamnya. Mereka membentuk keluarga dalam perkawinan, tetapi mempertahankan eksistensi pribadi dalam kaumnya masing-masing.

Laki-laki memiliki kekuatan dan kekuasaan, tetapi tidak memiliki hak atas harta dan keturunan. Mereka hidup berkampung-kampung, tetapi membelah dirinya dalam bersuku-suku. Mereka tinggal bersama dalam rumah besar, tetapi hidup berbilik-bilik. Mereka juga mempunyai kebanggaan kaum secara fanatik, tetapi tidak membesarkan diri untuk mengalahkan orang lain.

Dalam buku Pattern of Culture, Benedict menegaskan pentingnya memahami pola-pola budaya untuk memahami perbedaan di antara kelompok masyarakat. Pola budaya itu perlu dikaji secara mendalam untuk menemukan sesuatu yang lebih inti dan dalam yang mengarah kepada gagasan, nilai, dan sesuatu yang mengarakterkan masyarakat tertentu. Dalam perspektif Benedict, ritual berburu babi demikian mendarah daging dan memperlihatkan pola budaya masyarakat Minangkabau. Bertahannya tradisi dari perubahan juga memperlihatkan bahwa berburu babi memiliki fungsi tertentu di dalam masyarakat Minangkabau. Fungsi yang akan dikaji dalam studi ini adalah fungsi tradisi sebagai sebuah drama sosial.

Ada dua masalah di dalam tulisan ini. Pertama, makna ritus buru babi dalam masyarakat Minangkabau dan bagaimana konstruksi sosial dari proses ritual tradisi buru babi masyarakat Minangkabau sebagai sebuah drama sosial. Jawaban atas kedua masalah itu akan menjelaskan bahwa tradisi tersebut merupakan sebuah drama sosial yang memiliki fungsi-fungsi penting di dalam masyarakat Minangkabau.

Ritus dan upacara adalah komponen penting dalam sistem religi. 
Ritus dan upacara dalam sistem religi berwujud aktivitas dan tindakan manusia untuk berkomunikasi dan melaksanakan kebaktiannya terhadap Tuhan, dewadewa, roh nenek moyang, atau makhluk gaib lainnya (Koentjaraningrat, 1987). Ritus atau upacara religi biasanya berlangsung secara berulang-ulang, baik setiap hari, setiap musim, atau kadangkadang saja. Sebuah ritus atau upacara religi biasanya terdiri atas suatu kombinasi yang merangkaikan satu, dua, atau beberapa tindakan, seperti berdoa, bersujud, bersaji, berkorban, makan bersama, berpuasa, bertapa, dan bersemedi. Hal itu bergantung pada jenis ritual yang sedang dijalankan. Ritual merupakan tata cara dalam upacara atau suatu perbuatan keramat yang dilakukan oleh sekelompok umat beragama. Hal itu ditandai dengan adanya berbagai macam unsur dan komponen, yaitu adanya waktu, tempat upacara, alat-alat upacara, dan orang-orang yang menjalankan upacara.

Pada dasarnya, ritual adalah rangkaian kata, tindakan pemeluk agama dengan menggunakan benda-benda, peralatan, dan perlengkapan tertentu, dilaksanakan di tempat tertentu, dan memakai aksesoris dan pakaian tertentu pula. Ritual atau ritus dilakukan dengan tujuan tertentu, misalnya untuk mendapatkan berkah, rezeki yang banyak, dan mengusir teluh atau penyakit. Ritus dapat pula dilakukan untuk menolak bala karena perubahan atau siklus dalam kehidupan manusia, seperti kelahiran, pernikahan, dan kematian (Bustanuddin, 2007).

Salah satu tokoh antropologi yang membahas ritual adalah Victor Turner (Winangun, 1990). Menurut Turner, ritus-ritus yang diadakan oleh suatu masyarakat merupakan penampakan dari keyakinan religius. Ritus yang dilakukan itu mendorong orang-orang melakukan dan menaati tatanan sosial tertentu. Ritus juga memberikan motivasi dan nilai-nilai pada tingkat yang paling dalam. Menurut Victor Turner, ritus memiliki empat peranan, yakni (1) menghilangkan konflik,(2) membatasi perpecahan dan membangun solidaritas masyarakat, (3) mempersatukan dua prinsip yang bertentangan, dan (4) memberikan kekuatan dan motivasi baru untuk hidup dalam masyarakat sehari-hari.

Secara umum, Turner menggolongkan dan membedakan ritus atas dua bentuk, yaitu ritual krisis hidup dan ritual gangguan (Turner, 1969; Winangun, 1990). Ritus kritis hidup ialah tindakan ritual yang berhubungan dengan krisis hidup manusia. Ritus krisis hidup diadakan saat manusia mengalami krisis-krisis dalam hidupnya, terutama karena beralih dari satu tahapan kehidupan ke tahapan berikutnya. Ritus krisis hidup manusia meliputi kelahiran, pubertas, perkawinan, dan kematian. Ritus-ritus itu tidak hanya berpusat pada kritis yang dialami seorang individu, tetapi juga tanda adanya perubahan dalam relasi sosial di antara orang yang berhubungan dengan mereka, dengan ikatan darah, perkawinan, kontrol sosial, dan sebagainya. Ritus gangguan ialah ritual negosiasi dengan roh agar tidak mengganggu kehidupan manusia. Pada ritus gangguan itu masyarakat melakukan tindakan negosiasi dengan alam, roh leluhur, dan dewa-dewa agar mereka terhindar dari nasib sial dalam berburu, ketidakteraturan reproduksi pada para wanita, dan sebagainya.

Dalam pandangan Weber, tindakan-tindakan ritual keagamaan merupakan sebuah tindakan sosial di dalam masyarakat. Dalam pemahamannya, tindakan sosial berorientasi kepada nilai tertentu, termasuk nilai keagamaan. Weber menginterpretasikan tindakan keagamaan dengan memahami motif- 
motif sang aktor dari sudut pandang subjektif (Weber, 1978).

Jika dipahami secara lebih terperinci, tampak bahwa banyak genre tradisi lisan, misalnya mantra, tutu maring asa-usu, nololo, dan bini, yang didaraskan dalam berbagai pertemuan ritual formal (misalnya pengobatan orang sakit, pembukaan lahan baru, persiapan perang, dan upacara kematian) memiliki fungsi liminalitas sebagai sebuah tahap inisiasi untuk menuju sebuah integrasi baru. Posisi tukang cerita dan pendengarnya berada di nomor 2 (liminality) atau fase transisi (sebuah masa ambang). Semua pertemuan ritual formal biasanya mengikuti tiga fase tersebut, yakni (1) fase separation (memisahkan manusia lama, yaitu yang sakit, yang berharap, yang bersiap untuk perang, panen, membuka lahan baru, dari ruang dan waktu profan); (2) fase liminality (liminal, transisi), yaitu tahap upacara ritual dilangsungkan dengan berbagai tradisi lisan; dan (3) fase incorporation (penyatuan, integrasi) dengan terbentuknya manusia baru, yaitu yang sembuh dari sakit, terkabul harapannya, yang menang perang, memetik banyak hasil panen, atau sukses membuka lahan pertanian baru (Ruchika, 2016).

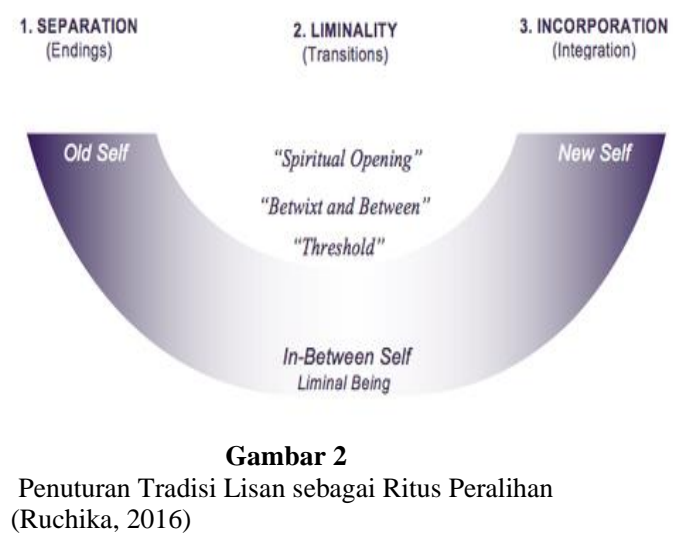

\section{METODE PENELITIAN}

Pendekatan yang digunakan dalam studi ini adalah pendekatan etnografis dengan menggunakan teori-teori yang dikenal di dalam ilmu antropologi. Metode utama penelitian ini adalah studi lapangan (field research) dengan menggunakan teknik observasi, wawancara, perekaman, pencatatan, dan penerjemahan. Interpretasi data menggunakan model penelitian kualitatif (Taum, 2011).

Penelitian ini mengkaji dan memahami tradisi berburu babi sebagai sebuah tradisi lisan yang dipraktikkan di dalam masyarakat Minangkabau. Dalam perspektif Turner (Ansari, 2019), tradisi berburu babi masyarakat Minangkabau dapat dipandang sebagai sebuah drama sosial yang mengandung unit-unit dari proses sosial disharmoni dan harmoni. Di dalam proses sosial ini terdapat empat fase drama sosial yang terdiri atas (1) breach of norm (pelanggaran norma), yang jika dikenakan ke dalam sistem berburu babi adalah fase pengenalan gangguan hama babi terhadap tanaman; (2) crisis, setelah mengetahui ancaman hama babi, masyarakat memasuki fase krisis ketika mengadakan berbagai upacara persiapan pelaksanaan berburu babi; (3) redressive actions, tindakan pemulihan dengan melaksanakan upacara berburu babi; (4) reintegration or schism, kembali ke situasi normal (Hansen et al., 2019).

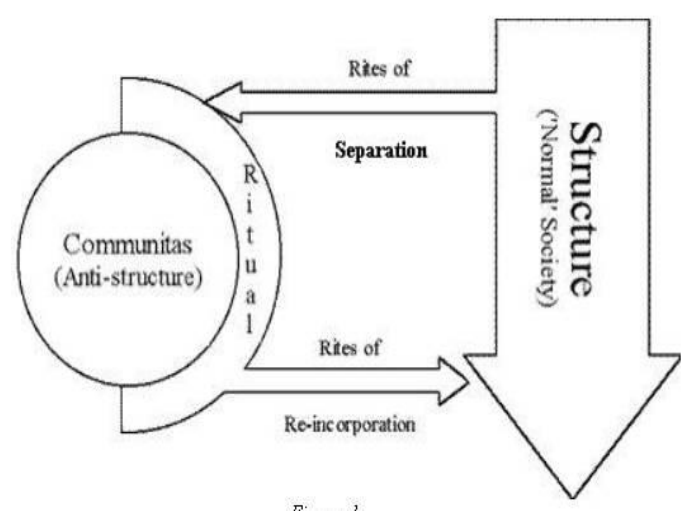




\section{PEMBAHASAN}

\section{Sekilas tentang Padang Pariaman}

Berdasarkan letak daerahnya, menurut Ediwar, Padang Pariaman dapat dibagi menjadi dua, yaitu daerah pesisir dan pedalaman (Ediwar, 1999). Daerah pesisir adalah daerah yang berbatasan langsung dengan pantai barat Sumatra dengan ketinggian $0-25$ meter dari permukaan laut, sedangkan daerah pedalaman merupakan daerah yang membujur ke arah pinggang Bukit Barisan yang mencapai ketinggian 1.500 meter dari permukaan laut.

Kabupaten Padang Pariaman merupakan daerah yang memiliki tingkat kepanasan udara yang cukup tinggi, apalagi di kawasan yang dekat pantai. Daerah pantai merupakan daerah yang dipenuhi oleh rawa dan hanya bisa ditumbuhi daun nipah, rumbia, dan kelapa. Daerah pedalaman memiliki banyak areal pertanian dan perkebunan padi dan sayuran yang dipanen secara periodik. Perkebunan menghasilkan buah-buahan, seperti durian, manggis, kopi, dan pala.

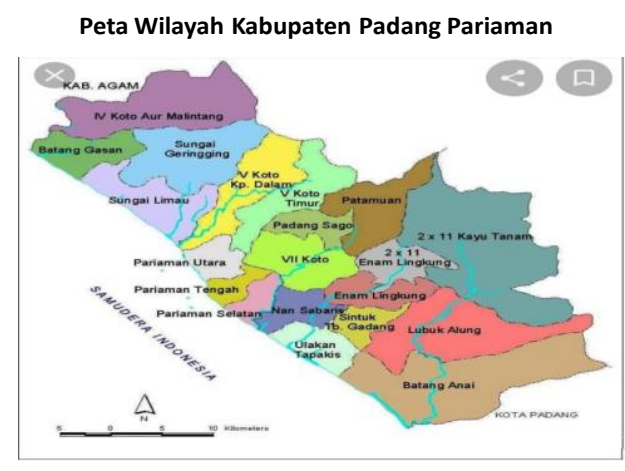

Sistem ekonomi dan mata pencaharian masyarakat Kabupaten Padang Pariaman ditentukan oleh keadaan alam yang melingkupinya. Hasil sektor pertanian daerah rantau Pariaman didominasi oleh tanaman padi (khususnya padi sawah). Hal itu terlihat dari luasnya areal tanaman padi yang lebih banyak jika dibandingkan dengan areal tanaman lainnya. Hasil kebun merupakan hasil sampingan setelah hasil pertanian. Pariaman merupakan penghasil terbesar kelapa di Sumatra Barat. Tanaman perkebunan lainnya adalah karet, cengkeh, kayu manis, kopi, pala, kapuk, durian, dan manggis. Buah-buahan yang cukup terkenal adalah durian dan manggis. Kedua jenis buah-buahan itu umumnya dipanen bersamaan.

Melihat sejarahnya, Pariaman pernah memiliki pelabuhan laut. Mansoer menjelaskan bahwa Bandar Pariaman dan Tiku terkenal sebagai daerah pelabuhan terpenting (Mansoer, 1970). Pesisir barat Sumatra merupakan daerah yang dilewati kapal-kapal yang membawa lada dan emas. Hingga menjelang akhir abad ke-17, Belanda menjadikan kota Padang sebagai pos dagang terpenting sehingga Pariaman menjadi bandarnya. Jelas terlihat bahwa masyarakat Padang Pariaman memiliki jiwa dagang yang besar karena pengaruh masa lalu. Mereka tidak hanya berdagang di daerahnya, tetapi juga mengadu nasib di rantau yang lebih luas.

\section{Makna dan Proses Ritual Buru Babi}

Buru babi pada hakikatnya merupakan sebuah ritus gangguan di dalam kategori Turner dengan proses ritual yang melibatkan masyarakat. Babi hutan dipandang sebagai hama yang merusak tanaman pertanian dan menjadi ancaman bagi penduduk. Untuk menghilangkan gangguan tersebut, masyarakat Minangkabau melaksanakan proses ritual yang menggunakan rangkaian kata, benda-benda, peralatan, dan perlengkapan tertentu, dilaksanakan di tempat tertentu, dan dengan aksesoris dan pakaian tertentu pula. Berikut diterangkan tahap-tahap atau proses ritual buru babi, dimulai dari sebelum, 
selama, dan ritual penutupan setelah buru babi.

\section{Tahap Persiapan Buru Babi}

Beberapa hari sebelum dilakukan aktivitas buru babi, muncak buru (penanggung jawab aktivitas berburu) mendatangi kapalo mudo sebagai orang yang dipilih ninaik mamak mengurus kegiatan dalam nagari. Muncak buru melaporkan gangguan hama babi yang melanda lahan pertanian dan meminta izin serta mengundang niniak mamak untuk hadir pada aktivitas buru babi yang telah direncanakan sebelumnya.

Pada pagi hari, pelaksanaan aktivitas buru babi itu, kapalo mudo dan muncak buru menyambut kedatangan tamu undangan yang datang dari luar kampung. Mereka dijamu di balai pertemuan adat terbuka (laga-laga) dengan makanan ringan dan minuman (teh dan kopi) yang disediakan oleh perempuan yang telah ditunjuk kapalo mudo, dengan sirih dan rokok dalam carano.

Mereka duduk di tikar dengan pola melingkar dalam pertemuan jelang buru babi yang disebut ghundiang lapiak. Ghundiang lapiak merupakan penyambutan kedatangan pemburu secara resmi yang dihadiri perangkat adat (ninik mamak, datuak atau penghulu, wali nagari, dan kapalo mudo), muncak buru, dan wakil pemburu dari tiap wilayah di Minangkabau. Ghundiang lapiak dimulai dengan doa sebagai rasa syukur kepada Tuhan, sambutan dari kapalo mudo, dan dilanjutkan dengan diskusi menggunakan pasambahan, yaitu dialog berbalasan dengan pepatah petitih yang merupakan adat bertutur kata khas masyarakat Minangkabau.

Prosesi pasambahan merupakan bentuk aksi sosial yang memperlihatkan eksistensi setiap individu yang hadir.
Aksi sosial berkaitan dengan interaksi dengan perorangan atau kelompok masyarakat, terlihat dari adanya aksi dan reaksi serta mengandung rangsangan dan respons (Soekanto, 1975). Aksi sosial merupakan bagian dari pekerjaan sosial yang memiliki komitmen untuk menjadi agen atau sumber bagi mereka yang berjuang menghadapi beragam masalah. Pasambahan menjelang buru babi disampaikan dengan kata-kata yang mempunyai arti ganda atau bersifat permainan kata (pamenan kato). Martabat kata yang mengisyaratkan permainan kata yang memiliki makna ganda juga terdapat pada pasambahan menjelang buru babi. Salah satu contoh kata yang penting dalam kebudayaan Minangkabau terdapat pada pantun berikut.

Patitieh pamenan andai,

Gurindam pamenan kato.

Pangulu kalau tak pandai,

Nagari caie kampuang binaso

Petitih permainan andai

Gurindam permainan kata

Penghulu kalau tak pandai

Negeri hancur kampung binasa

Dalam pasambahan menjelang berburu babi, manusia yang terlibat adalah para petinggi adat dan mereka yang pandai dalam pasambahan. Ajaran adat Minangkabau meletakkan manusia sebagai salah satu unsur yang statusnya sama dengan unsur penting lainnya, seperti tanah, rumah, suku, dan nagari. Setiap manusia, secara kelompok atau pribadi, memerlukan tanah, rumah, suku, dan nagari sebagaimana mereka memerlukan manusia atau orang lain bagi kepentingan lahir dan batinnya. Manusia merupakan sesuatu yang sempurna dibandingkan dengan makhluk lainnya. Jika tidak mempertimbangkan rasa dan periksa, ia dianggap sebagai manusia yang tidak lengkap. Oleh 
karena itu, setiap manusia atau orang dipandang dalam status yang sama. Tagak samo tinggi, duduak samo randah ${ }^{1}$.

Menurut Jamaris, nilai-nilai budaya yang menonjol dalam acara pasambahan ialah sebagai berikut (Jamaris, 2002). Pertama, nilai kerendahan hati. Orang yang rendah hati selalu menghargai orang lain. Hal itu dapat dilihat pada awal acara pasambahan. Juru sambah (orang yang ahli pasambahan) dari tuan rumah menyapa semua tamu satu per satu dengan menyebut gelar adatnya sebagai tanda bahwa semua tamu dihargai oleh tuan rumah. Sesudah itu barulah juru sambah memulai sambutannya, menyampaikan maksud dan tujuan kepada para tamu.

Kedua, nilai musyawarah. Segala sesuatu yang dilakukan dan diputuskan selalu dimusyawarahkan terlebih dahulu. Juru sambah yang akan tampil ditentukan terlebih dahulu melalui musyawarah. Demikian pula jawaban yang akan disampaikan.

Ketiga, nilai ketelitian dan kecermatan. Juru sambah dalam upacara pasambahan harus teliti dan cermat mendengarkan apa yang diucapkan oleh juru sambah lawan bicaranya.

Keempat, nilai budaya ketaatan dan kepatuhan terhadap adat yang berlaku. Dalam upacara pasambahan itu segala sesuatu yang akan dilakukan ditanyakan dulu apakah sesuai dengan adat yang berlaku. Salah satu syarat pokok permintaan dapat disetujui adalah permintaan itu sesuai dengan aturan adat yang berlaku.

Di dalam ritual rundiang lapiak itu ada beberapa acara penting yang harus dilaksanakan, yaitu (a) evaluasi perburuan sebelumnya, (b) penetapan

${ }^{1}$ Tegak sama tinggi, duduk sama rendah. Manusia memiliki kepentingan yang sederajat. Manusia harus menghargai kepentingan orang lain. daerah perburuan selanjutnya, dan (c) menjelaskan aturan perburuan hari itu sesuai dengan hasil pencari jejak babi hutan oleh tukang tapak (pencari jejak). Evaluasi terhadap perburuan sebelumnya, semua peristiwa yang terjadi di perburuan, seperti anjing yang luka, orang yang sakit, dan mambukak uncang, mengumpulkan bantuan sebagai bentuk kepedulian, diserahkan kepada yang bersangkutan. Pada bagian ini ditentukan tempat perburuan berikut dan mengangkat muncak yang akan memimpin perburuan berikutnya.

Aturan perburuan dan aturan main yang akan dilaksanakan pada hari itu dijelaskan dan mesti dipatuhi oleh semua peserta perburuan. Pada bagian itu juga dijelaskan bagaimana perburuan itu dimulai, yaitu dengan menjelaskan lokasi perburuan untuk diketahui oleh semua peserta. Di tengah lingkaran duduk mereka disediakan sirih dalam carano dan juadah yang berisi makanan dan minuman.

Susunan acara rundiang lapiak selalu diisi dengan doa pembukaan, sambutan, makan bersama, diskusi, diakhiri dengan doa penutup. Dalam rundiang lapiak, para perempuan berperan sebagai orang yang menyediakan makanan dan minuman di rumah. Makanan dan minuman itu dibawa oleh janang, yaitu orang yang bertugas mengurus pertemuan itu. Perempuan tidak diperkenankan turut serta dalam rundiang lapiak. Makanan yang disajikan biasanya makanan ringan sebagai sarapan pagi, seperti sala lauak, onde-onde, goreng pisang dengan ketan, dan kopi atau teh. Dalam ritual ini digunakan pula benda-benda ritual, seperti kemenyan yang dibakar sebelum rundiang lapiak dibuka dan diletakkan di tengah dekat carano yang berisi sirih dan rokok, beras ataran dalam nampan yang disertai rokok dan uang kertas diletakkan di luar lingkaran. Benda- 
benda itu dipercaya sebagai pembujuk roh-roh agar menjauh sehingga hajat yang akan dilaksanakan berlangsung dengan lancar.

\section{Tahap Pelaksanaan Buru Babi}

Setelah rangkaian upacara adat dilakukan, para pemburu akan mulai bersiap-siap memasuki kawasan hutan belukar, tempat babi hutan lewat bersama rombongannya. Para pemburu, selain membawa anjing, ada yang membawa bedil atau badia lansa yang juga digunakan untuk menembak babi. Anggota perburuan menjadi tanggung jawab muncak buru yang ditandai dengan pemakaian deta pada tubuh mereka. Deta adalah kain batik segi empat yang dilipat dua menyilang, dipakai di kepala atau dilingkarkan di leher.

Pada umumnya berburu babi hutan dilakukan oleh kalangan laki-laki dewasa atau mereka yang sudah cukup umur dan memiliki keterampilan berburu. Berburu babi hutan bukanlah suatu perkara mudah karena pemburu harus menguasai teknik dasar perburuan.

Kegiatan berburu babi hutan dilakukan pada pagi hari hingga menjelang sore. Babi yang mati hasil buruan akan dibiarkan tergeletak begitu saja di dalam hutan. Navis mengatakan bahwa proses pengembangan permainan rakyat (termasuk buru babi) di Minangkabau sejalan dengan proses pengembangan kehidupan sosialnya (Navis, 1984).

Ketika memasuki hutan, para pemburu berkumpul di karan, tempat permulaan buru babi dilakukan. Para pemburu telah siap dengan anjing-anjing mereka yang terkekang. Muncak buru memimpin perburuan dan memulai serta memberi instruksi melepaskan anjing dan mengarahkan pemburu ke hutan dengan sorak atau kuai (teriakan) yang disambut teriakan pemburu lainnya sambung-menyambung. Selain salak anjing, bunyi letusan badia lansa merupakan penanda bahwa seseorang berhasil membunuh babi.

Pada zaman sekarang orang berburu sudah menggunakan fasilitas yang modern. Sebelum dilakukan perburuan, para pemburu berdatangan dengan membawa beberapa ekor anjing. Setelah semuanya berkumpul di lokasi, para pemburu akan dibagi atas beberapa kelompok yang nantinya akan masuk ke dalam hutan.

Pemakaian fasilitas modern merupakan bentuk perubahan dalam sebuah kebudayaan. Abdullah menjelaskan bahwa perubahan dimensi waktu dan jarak tidak saja mempertinggi tingkat keseringan dalam perkunjungan, tetapi lebih penting lagi mengecilkan rasa keasingan. Artinya perbedaan antara mana yang kita dan mana yang mereka makin mengabur. Dalam suasana seperti itu komunikasi yang berjalan lebih lancar bukanlah hal yang terlalu aneh karena merupakan akulturasi (Abdullah, 1983).

\section{Tahap Penyelesaian}

Setelah seharian berburu babi, para lelaki pemburu berkumpul kembali di karan, tempat permulaan perburuan. Selanjutnya wakil-wakil pemburu, muncak buru, dan kapalo mudo kembali duduk di laga-laga. Mereka melaporkan jumlah babi hutan yang berhasil dilumpuhkan, anjing yang terluka, dan pemburu yang terluka. Jika ada anjing atau pemburu yang terluka, mereka mengedarkan carano yang beralaskan kain deta di bawahnya sebagai pertanda berburu. Carano itu akan diisi oleh yang hadir sebagai sumbangan untuk mengobati anjing atau pemburu yang terluka. Bagian ini disebut mambukak uncang yang kemudian diserahkan 
muncak buru saat mengunjungi ke rumah pemburu yang terluka. Mambukak uncang merupakan bentuk solidaritas sesama pemburu untuk meringankan pemburu yang mengalami kecelakaan di perburuan. Rundiang lapiak ditutup dengan doa sebagai rasa syukur telah terlaksananya buru babi, ucapan terima kasih dari kapalo mudo, ucapan terima kasih penjagaan yang baik dari pihak tuan rumah sejak pagi hingga sore harinya dengan hidangan makanan ringan dan minuman kopi dan teh.

Dari uraian di atas, dapat diungkap bahwa fungsi ritual berburu babi dalam masyarakat Minangkabau ialah sebagai berikut. Pertama, ritus yang dapat menghilangkan konflik di dalam Masyarakat. Permasalahan yang terjadi dalam masyarakat terkait dengan gangguan hama babi diatasi dengan melakukan aktivitas buru babi yang dilaksanakan secara bersama-sama dengan ritual rundiang lapiak sebelum melakukan perburuan di hutan sekitar pertanian. Berkumpulnya masyarakat di dalam sebuah aktivitas bersama dapat mencairkan ketegangan dan konflik di antara anggota masyarakat. Mereka secara bersama-sama menghadapi musuh bersama sehingga dengan sendirinya bersatu padu.

Kedua, ritus yang dapat membatasi perpecahan dan membangun solidaritas masyarakat. Rundiang lapiak yang dilakukan sebelum berburu babi merupakan bentuk musyawarah yang menyatukan masyarakat yang memiliki keinginan sama, menjaga lahan pertanian mereka dengan cara bergotong royong. Pemburu datang dari berbagai wilayah di Minangkabau untuk bergilir membasmi hama babi hutan. Musyawarah dan gotong royong sebagai masyarakat komunal terjaga dan berjalan dengan baik. Aktivitas buru babi menciptakan kehidupan yang lebih baik karena gangguan yang cukup berat itu tidak akan mampu diatasi sendiri. Aktivitas buru babi dengan rangkaian ritualnya telah menciptakan semangat dan motivasi hidup yang lebih baik dengan harapan besar terhadap hasil pertanian yang mampu mengatasi persoalan ekonomi.

Ketiga, ritus yang mempersatukan dua prinsip yang bertentangan. Pasambahan menjelang buru babi disampaikan dengan kata-kata yang mempunyai arti ganda atau bersifat permainan kata (pamenan kato). Dalam rundiang lapiak itu, manusia yang terlibat adalah para petinggi adat dan mereka-mereka yang pandai dalam pasambahan. Musyawarah yang dilakukan dalam rundiang lapiak ini yang menjalankan ajaran saiyo-sakato, bulek aia dek pambuluah, bulek kato dek mufakat. Rundiang lapiak yang digelar sebelum aktivitas buru babi dilakukan merupakan jalan yang ditempuh untuk menghindari konflik dan menyatukan pandangan dalam tujuan yang sama untuk memberantas gangguan hama babi hutan yang merusak lahan pertanian yang menjadi sumber kehidupan mereka bersama.

Walaupun saling berkompetisi, jarang terjadi konflik di antara mereka. Kalaupun ada, mereka bisa menyelesaikannya secara baik. Menurut Dahrendorf, ciri-ciri konflik dalam organisasi sosial ialah (1) sistem sosial senantiasa berada dalam keadaan konflik; (2) konflik-konflik tersebut disebabkan oleh adanya kepentingankepentingan yang bertentangan yang tidak dapat dicegah dalam struktur sosial masyarakat; (3) kepentingankepentingan itu cenderung berpolarisasi dalam dua kelompok yang saling bertentangan; (4) kepentingankepentingan yang saling bertentangan mencerminkan diferensiasi distribusi kekuasaan di antara kelompok-kelompok yang berkuasa dan dikuasai; 
penjelasan suatu konflik akan menimbulkan perangkat kepentingan baru yang saling bertentangan yang dalam kondisi tertentu menimbulkan konflik; dan (6) perubahan sosial merupakan akibat-akibat konflik yang tidak dapat dicegah pada berbagai tipe pola-pola yang telah melembaga (Craib, 1984; Pelly \& Menanti, 1994). Bagi Dahrendorf, sumber konflik adalah hubungan wewenang yang telah melembaga dalam asosiasi-asosiasi yang terkoordinasi secara imperatif. Dengan kata lain, sumber konflik adalah hubungan wewenang yang disahkan (legitimated authorities).

Keempat, ritus memberikan kekuatan dan motivasi baru untuk hidup dalam masyarakat sehari-hari. Ritual rundiang lapiak yang disampaikan dalam pasambahan menjelang buru babi disampaikan dengan kata-kata yang mempunyai arti ganda atau bersifat permainan kata (pamenan kato).

\section{Buru Babi sebagai Drama Sosial}

Dalam perspektif Victor W. Turner, seorang antropolog simbolik, tradisi berburu babi masyarakat Minangkabau dapat dipandang sebagai sebuah drama sosial yang mengandung unit-unit dari proses sosial disharmoni dan harmoni(Ansari, 2019). Di dalam proses sosial ini terdapat empat fase drama sosial sebagai berikut.

Pertama, breach of norm (pelanggaran norma). Gangguan yang dihadapi adalah munculnya hama babi yang merusak tanaman petani. Lahan pertanian yang subur, aman, dan hasil pertanian yang baik tentu menjadi impian setiap petani. Akan tetapi, timbulnya gangguan akan merusak hasil pertanian itu. Gangguan itu menjadi awal dilaksanakannya drama sosial yang kemudian melibatkan berbagai aspek masyarakat, seperti adat-istiadat, sastra, agama, ekonomi, dan strata sosial.

Kedua, crisis. Setelah mengetahui ancaman hama babi, masyarakat memasuki fase krisis ketika mereka mengadakan berbagai upacara persiapan pelaksanaan berburu babi. Ancaman babi hutan bukan lagi persoalan pribadi, melainkan persoalan masyarakat keseluruhan. Masyarakat pertanian bersepakat untuk menggelar perhelatan dengan melibatkan seluruh masyarakat sesuai dengan fungsinya masing-masing. Pemangku adat menyiapkan upacara adat rundiang lapiak, pemburu menyiapkan perburuan yang diatur oleh muncak buru sebagai pimpinan buru babi, perempuan menyiapkan juadah dan hidangan untuk ritual adat. Perhelatan itu juga mengundang peburu babi dari daerah lain. Undangan diperlakukan sebagai tamu kehormatan dan dilayani dengan keramahtamahan adat setempat.

Ketiga, redressive actions, yaitu tindakan pemulihan dengan melaksanakan upacara berburu babi. Tindakan yang dilakukan oleh masyarakat tidak hanya pelaksanaan buru babi, tetapi melibatkan adatistiadat, agama, dan ritual desa. Setelah dilakukan ritual adat rundiang lapiak sebagai bentuk musyawarah, buru babi dilaksanakan sesuai dengan ketentuan yang telah dibicarakan dalam ritual adat rundiang lapiak. Dahulu, akibat perburuan, banyak babi hutan yang mati. Mereka hanya mencatatnya sebagai hasil dan membiarkan bangkai babi hutan itu tergeletak. Lokasi perburuan yang jauh dari permukiman penduduk tidak akan berpengaruh besar terhadap lingkungan tempat tinggal. Seiring dengan perkembangan zaman dan imigrasi penduduk di Minangkabau, babi hutan yang mati itu akan diambil oleh orangorang dari kota yang berasal dari etnis lain untuk keperluan pesta dan makan mereka. 
Keempat, reintegration or schism, kembali ke situasi normal (Hansen et al., 2019). Usai pelaksanaan aktivitas buru babi, situasi pertanian kembali kepada keadaan sebelum hama babi hutan mengganggu. Petani kembali melakukan aktivitas seperti biasa dalam mengelola pertaniannya hingga panen selesai dengan hasil yang diharapkan. Akan tetapi, dampak terbesar dari pelaksanaan ritual buru babi adalah integrasi dan ikatan emosional masyarakat yang semakin kuat. Itulah nilai penting yang membuat tradisi buru babi terus berlangsung hingga kini.

\section{PENUTUP}

Buru babi dalam masyarakat Minangkabau merupakan sebuah ritus gangguan dalam kategori Turner yang dilaksanakan dalam sebuah proses ritual yang bertahap. Ritus buru babi menjadi sebuah penanda yang melibatkan berbagai aspek kehidupan masyarakat Minangkabau, seperti aspek sosial, ekonomi, religi, dan budaya. Peristiwa buru babi yang awalnya hanya merupakan upaya para petani menghilangkan hama tanaman berkembang menjadi sebuah drama sosial.

Ritus buru babi sebagai drama sosial memiliki empat fungsi, yaitu (1) menghilangkan konflik; (2) membatasi perpecahan dan membangun solidaritas masyarakat; (3) mempersatukan dua prinsip yang bertentangan; dan (4) memberikan kekuatan dan motivasi baru untuk hidup dalam masyarakat seharihari.

Sebagai sebuah drama sosial, tradisi buru babi hanya merupakan sebuah pemicu (trigger) yang menggugah peran individu di dalam sebuah konstruksi sosial. Di dalam proses sosial itu terdapat empat fase drama sosial, yaitu (1) pelanggaran norma sosial oleh hama babi yang mengundang masyarakat untuk bersatu melakukan pembasmian; (2) hama babi hutan mendatangkan ancaman yang nyata yang dapat menyengsarakan kehidupan masyarakat petani (krisis) sehingga masyarakat bersatu dan mengadakan berbagai upacara persiapan pelaksanaan berburu babi; (3) tindakan pemulihan krisis dengan melaksanakan upacara berburu babi; dan (4) mengembalikan masyarakat dengan seluruh tatanan sosialnya ke dalam situasi normal.

\section{DAFTAR PUSTAKA}

Abdullah, T. (1966). Adat and Islam: An Examination of Conflict In Minangkabau. Jurnal Indonesia, 2. https://doi.org/10.2307/3350753

Abdullah, Taufik. (1983). Remaja Minangkabau di Perantauan sebagai Gejala Kultural. In A. A. Navis (Ed.), Dialektika Minangkabau dalam Kemelut Sosial dan Politik (pp. 144-154). Padang: Genta Singgalang Press.

Adisaputri, Y. D., \& Widiastuti, I. (2014). Kajian Ruang Liminal pada Konsep Teritori Pemukiman Adat Sunda Cigugur melalui Analisis Ritual "Ngajayak". Prosiding Temu Ilmiah IPLBI.

Ansari, I. (2019). Drama Sosial Victor Witer Turner: Penelusuran Basis Epistemologis dan Paradigma.

Arifin, Z. (2012). Buru Babi: Politik Identitas Laki-laki Minangkabau. Humaniora, 29-36.

Bustanuddin, A. (2007). Agama dalam Kehidupan Manusia. Jakarta: Raja Grafindo Persada.

Craib, I., \& (Penerj.), P. S. B. \& T. E. (1984). Teori-teori Sosial Modern: Dari Parsons sampai Habermas. Jakarta: Rajawali Press.

Ediwar. (1999). Perjalanan Kesenian 
Indang dari Surau ke Seni Pertunjukan Rakyat Minangkabau di Padang Pariaman, Sumatera Barat. Universitas Gadjah Mada.

Graves, E. E., \& Novi Andri dkk. (Penerj.). (2007). Asal-usul Elite Minangkabau Modern: Respon terhadap Kolonial Belanda Abad XIX/XX. Jakarta: Obor.

Hansen, F., Berntsen, G. K. R., \& Salamonsen, A. (2019). Patient pathways as social drama: a qualitative study of cancer trajectories from the patient's perspective. London: Taylor and Francis. https://doi.org/10.1080/17482631. 2019.1639461

Jamaris, E. (2002). Pengantar Sastra Rakyat Minangkabau. Jakarta: Obor.

Koentjaraningrat. (1987). Sejarah Teori Antropologi I. Jakarta: UI Press.

Mansoer, M. D. et al. (1970). Sejarah Minangkabau. Jakarta: Beratara.

Navis, A. A. (1984). Alam Terkembang Jadi Guru Adat dan Kebudayaan Minangkabau. Jakarta: Grafiti Press.

Pelly, U., \& Menanti, A. (1994). TeoriTeori Sosial Budaya. Jakarta: Depdikbud.

Ruchika. (2016). Rites of Passage. The Sociological Conversance: The Excitement of Finding the Familiar Becoming Transformed in Its Meaning.

https://sociovillage.wordpress.com /2016/06/27/rites-of-passage/

Soekanto, S. (1975). Sosiologi Suatu Pengantar. Jakarta: Rajawali Press.

Taum, Y. Y. (2011). Studi Sastra Lisan: Sejarah, Teori, Metode, dan Pendekatan Disertai Contoh Penerapannya. Yogyakarta: Lamalera.

Turner, V. (1969). The Ritual Process,
Structure and Anti-structure. New York: Cornell Univ. Press.

Weber, M. (1978). Economy and Society. An Outline of Interpretative Sociology (G. Roth \& C. Wittich (eds.). California: Univ. of California.

Winangun, Y. W. W. (1990). Masyarakat Bebas Struktur, Liminitas dan Komunitas Menurut Victor Turner. Yogyakarta: Kanisius. 